\title{
Does The (Largely Unknown) Administrative Law Process Protect Or Abuse Citizens' Rights?
}

Robert B. Matthews, JD, Sam Houston State University, USA

Tommy J. Robertson, JD, Sam Houston State University, USA Laura Sullivan, JD, Sam Houston State University, USA

\begin{abstract}
Administrative law consists generally of the rules, orders, and decisions of federal, state, and local government agencies established to perform a specific function. The Administrative Procedure Act, other legislation, and court decisions have established administrative agencies as a large power base, largely insulated from electoral accountability, at both the federal and state levels. Most citizens are unaware of the extent of such power, and of the extent such power can be exercised with minimal transparency. This paper reviews and evaluates the federal administrative law process, examines differing practices followed in various states and foreign countries, and suggests potential changes to make the process more accountable and transparent, and to preserve better the rights of parties to both procedural and substantive due process.
\end{abstract}

Keywords: Administrative Law; Administrative Procedure Act (APA); Constitution; Separation of Powers

When the legislative and executive powers are united in the same person, or in the same body of magistrates, there can be no liberty. -- Montesquieu, The Spirit of the Laws

\section{INTRODUCTION}

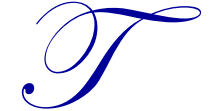

he United States Constitution clearly provides for the separation of federal powers among Legislative, Executive, and Judicial branches.

Article. I. Section. 1. All legislative Powers herein granted shall be vested in a Congress of the United States, which shall consist of a Senate and House of Representatives.

- $\quad$ Article. II. Section. 1. The executive Power shall be vested in a President of the United States of America.

- $\quad$ Article III. Section. 1. The judicial Power of the United States shall be vested in one Supreme Court, and in such inferior Courts as the Congress may from time to time ordain and establish.

Administrative agencies typically combine in one entity the functions associated with the three Constitutional branches of government. Administrative agencies make, enforce, and adjudicate legislative or substantive rules that are as legally binding as laws that Congress passed. Administrative agencies are sometimes referred to as the "fourth branch" of the U.S. government. The Administrative Procedure Act (APA) establishes a process for administrative agencies that includes three functions:

- $\quad$ Legislative - Rulemaking is the formulation of new regulation. Rulemaking is conducted pursuant to procedures established by the APA. Rulemaking follows a "Notice and Comment" process that involves four steps:

$\circ \quad$ Notice of the proposed rulemaking (NOPR or NPRM).

- Comment Period.

$\circ \quad$ Hearing

2013 The Clute Institute http://www.cluteinstitute.com/ 
○ The Final Rule.

- $\quad$ Executive - Compliance with the rules is investigated and enforced by the executive director and staff. Investigation and enforcement include the powers to:

- Conduct Inspections.

○ Issue Subpoenas.

- $\quad$ Judicial - Disputes are adjudicated before an administrative law judge or hearings examiner. The APA provides a mechanism for administrative adjudication of suspected rule violations, including the following steps:

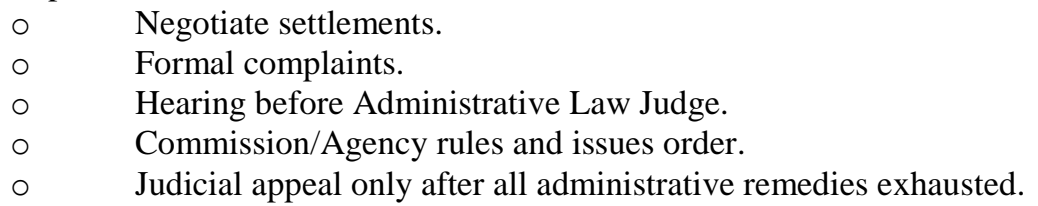

Note that the APA also provides that it is the agency itself that is the final decision maker, and has discretion and latitude in overruling the ALJ (Universal Camera Corp. v. NLRB, 1951).

Article I of the Constitution has been held to authorize delegating such powers to administrative agencies. This apparent violation of the separation of powers principles is generally permitted so long as

- $\quad$ The enabling legislation creating the agency

○ Is "sufficiently specific and detailed to meet constitutional requirements" (Mistretta v. US, 1989)

○ Is complied with by the agency

- $\quad$ The parties are afforded procedural due process--notice and a hearing (Morgan v. U.S, 1938)

If these factors are present, then the proceeding is deemed-as a matter of law-to have afforded the parties both procedural and substantive due process.

There are two basic types of administrative agencies:

- Executive Agencies, which are Cabinet-level departments of the Executive Branch and their subdepartments.

- Independent Regulatory Agencies, which are agencies outside the major executive departments such as the Federal Aviation Administration or the Federal Communications Commission

In theory, all three constitutionally created branches of government have some measure of control over administrative agencies.

- $\quad$ Executive. The President appoints members to agency governing bodies. The agencies themselves reside at least nominally in the Executive Branch. The President generally exercises more control over Executive Agencies than Independent Regulatory Agencies.

- $\quad$ Legislative. Enabling legislation is a law passed by Congress to specify the name, purposes, functions, and powers of administrative agency. Federal administrative agencies may exercise only those powers that Congress has delegated to them in enabling legislation. The Senate confirms Presidential appointees to administrative agency governing bodies pursuant to the "advice and consent" provision (Article II, Section 2, Clause 2).

- Judicial. The APA provides for judicial review of most agency actions. A party seeking review must

- Demonstrate standing to sue,

- Show an actual controversy at issue, and

- Have exhausted all possible administrative remedies. 
- Judicial review of agency action will frequently address whether the agency has

$\circ \quad$ Acted beyond its authority or

- Failed to discharge its responsibility.

Administrative law has been defined as that branch of the law dealing with the organization, powers and duties of administrative agencies, the legal requirements governing their operation, and the remedies available to those adversely affected by administrative action. In the Anglo-American legal system, administrative law concerns itself with the delegation of legislative and judicial powers to the Executive Branch, the manner in which such powers may be exercised, and judicial control of the administrative agency. (Darity, 2008)

\section{CRITICISMS}

The rulemaking, enforcement, and adjudication processes associated with administrative agencies have all been criticized on various grounds. Criticisms in each area may be summarized as follows:

\section{Rulemaking}

The delegation of rulemaking powers from Congress to an administrative agency under the Executive Branch has been criticized on several grounds:

- Delegation breeds political irresponsibility by allowing Congress to claim credit for the benefits it provides without being held accountable for the accompanying costs.

- Delegation creates a process where special interests and their lobbyists are represented in great strength, while the general public is essentially without representation.

- $\quad$ Delegation breed an increasingly large and expensive and potentially unaffordable government.

Defenders of delegation have sought to make the following arguments to offset those claims:

- Technical expertise is required.

- $\quad$ Congress is too busy to vote on detailed policies and procedures.

- $\quad$ A complex world requires complex rules, and therefore rulemaking must be the province of experts.

\section{Enforcement}

The enforcement power is probably the least subject to structural criticism, primarily because agencies reside in the Executive Branch and enforcement is constitutionally the responsibility of the Executive Branch, so the separation of powers issues do not really apply to this function. Criticisms do include the following:

- $\quad$ Enforcement and rulemaking functions are largely performed by the same staff personnel, resulting in some blurring of lines between the two functions.

- The problem of the "revolving door," where agency staff personnel are hired by entities subject to regulation by the agency, or legal or consulting firms employed by such entities, cannot be prevented completely, and existing rules regarding cooling off periods are inadequate to ensure complete lack of conflicts of interest. This conflict of interest criticism can be extended further when staff personnel take positions as Administrative Law Judges.

- $\quad$ The agency staffs are fertile ground for the influence of lobbyists, particularly because so many agency proceedings receive far less scrutiny than do congressional proceedings.

- $\quad$ Agency staffs may exercise a degree of favoritism, as there is no real accountability to voters.

\section{Adjudication}

Kenneth Davis, author of the Administrative Law Treatise, has estimated that federal administrative "trials" outnumber federal court trials by a ratio of more than 6 to 1 and that up to 93 percent of all disputes are resolved in 
federal agency settings rather than in federal court settings. Thus, the sanctity of a citizen's rights rests largely on the justice of administrative procedures (Bovard 1999).

The General Accounting Office reported in 1992 that administrative law judges in six federal agencies believed that the agency had attempted to "compromise their independence." One administrative law judge at the Interior Department told the ABA Journal: "We do operate in a wholly vindictive and retaliatory environment." Edward Slavin of the Government Accountability Project in Washington, D.C., observed, "Rather than having the independence of a district court judge, administrative law judges [ALJs] are essentially on the payroll and subjected to the pressure of the agencies." Rep. Barney Frank observed in 1990, "We have gotten allegations from administrative law judges of coercion, threatened transfers, and other kinds of pressures." Yet citizens are forced to spend months or years slogging through these systems as if they were real judicial systems (Bovard 1999).

The Labor Department's Office of Federal Contract Compliance Programs (OFCCP) routinely demands that private companies pay millions of dollars in back wages to people never hired by the company, on grounds that federal judges might likely reject. According to former OFCCP director Ellen Shong Bergman, OFCCP officers are sometimes guilty of "attempted extortion" in their threats against businesses that fail to hire and promote sufficient numbers of minorities and women. Before a federal contractor can get access to a federal judge to rule on the legality of the OFCCP's demands, the company must spend three or more years exhausting the Labor Department appeals processes and hearings before Labor Department ALJs. Even if an ALJ finds against the agency, the political appointees on the board can simply overturn the ALJ's decision (Bovard 1999).

\section{PROPOSALS}

This paper examines several possible approaches:

- $\quad$ Requiring Congressional approval and ratification of new agency rulemaking within a reasonable period of time before such rules can take effect, as above; and/or

- Implementing a sunset provision requiring that Congress approve and ratify existing rules on a ten-year cycle; and/or

- Moving the Administrative Law tribunals out of the individual agencies and into a separate and at least quasi-independent office of administrative hearings, as several states have done; or

- $\quad$ Creating new Article III courts within the Judicial Branch, to specialize in administrative law, as is common in continental Europe.

These proposals incorporate 1) processes that have worked at the state level in the US, and 2) approaches that have worked in foreign jurisdictions.

\section{Congressional Approval and Ratification of New Agency Rulemaking}

A number of members of Congress have proposed legislation to require Congressional approval and ratification of agency rulemaking before rules can take effect. These efforts have met with mixed success so far.

For example, in Immigration and Naturalization Service v. Chadha (1983) the Supreme Court majority of five justices, with one concurring, held that a veto by one house of an agency action was unconstitutional because Congress cannot grant itself a legislative veto inconsistent with the bicameralism principle and the Presentment Clause. Justice Powell, concurring, wrote that the legislative veto was essential to controlling the Executive Branch, but that a one-house veto was still unconstitutional. Justice White, dissenting, argued that the veto power was absolutely necessary to modern government.

In order to focus such approval process on the most significant new rules, such a provision could be made subject to some de minimis standard. For example, the Florida Administrative Procedure Act provides that if an agency rule is likely 1 ) to have an adverse impact on economic growth in excess of $\$ 1$ million within 5 years, 2) to have an adverse impact on business competitiveness in excess of $\$ 1$ million within 5 years, or 3) to increase regulatory costs in excess of $\$ 1$ million in within 5 years, then the rule must be ratified by the Legislature before it 
can take effect. Specific exemptions exist for emergency rules, rules adopting federal standards, and other specified cases (Joint Administrative Procedures Committee, 2010, p. 8).

\section{Congressional Sunset Review}

Sunset provisions provide that a particular agency, law, or regulation will expire on a certain date unless reauthorized by the legislative body. A number of states have adopted sunset review provisions requiring that administrative agencies be subject to review by an independent body on a periodic basis, and required at the time of such review to justify their continued existence, or be terminated. For example, under the Texas sunset provision established in 1977, all agencies - except universities, courts, and agencies established by the state constitution-are abolished after the passage of a specific period of time - typically 12 years - unless the state legislature specifically authorizes their continued existence and functioning. A 12-member panel-consisting of the Lieutenant Governor, five members of the House of Representatives, five members of the Senate, and one public member appointed by the Speaker of the House of Representatives - oversees the sunset provisions. Each agency performs a self-review, which is submitted to the panel, which then reviews the self-reported data, conducts additional procedures as it deems necessary, and makes a recommendation to the legislature. About 20 to 30 agencies go through the process each biennial legislative session (Texas Sunset Advisory Commission, 2012).

A federal sunset review process could include two components:

- $\quad$ A review of agencies on a periodic basis, and

- A review of rules issued by the agency, subject to the same de minimis standard adopted for new rules.

\section{Federal Office of Administrative Hearings}

Several states have separated the administrative law courts from the other functions of the agency. One indication that this is not a partisan issue is that states whose viewpoints on issues differ as much as Texas and Oregon have both adopted this approach. This approach breaks the link between the ALJ and the executive director of the agency. It does retain the issue of judicial action being taken within the Executive Branch.

\section{Article III Administrative Law Courts}

Civil law countries generally have a broader concept of administrative law. They typically have a separate system of administrative law courts. For example,

- In France most administrative law disputes are resolved through a system of administrative courts with the Conseil d'Etat (State Council) as the court of last resort. In addition to the areas of administrative law addressed in common-law jurisdictions, administrative law also includes the various forms of administrative agencies (what the French call the "subjects of rights" in administrative law), the exercise of and limits on administrative regulatory power, civil service law, acquisition and management of property by the government, public works, and the obligations of the government, including contract, quasi-contract, and tort (Darity 2008).

- In Germany the Administrative procedural law (Verwaltungsgerichtsordnung [VwVGo]) rules administrative procedures. The $\mathrm{VwVGo}$ is supplemented with the code of civil procedure (Zivilprozessordnung [ZPO]) and the judicature act (Gerichtsverfassungsgesetz [GVG]). The highest administrative court for most matters is the Bundesverwaltungsgericht (federal administrative court) with federal courts with special jurisdiction in the areas of tax law and social security law.

- Unlike France or Germany, Holland does not have special administrative courts of original jurisdiction, but regular courts have administrative "chambers" that specialize in administrative appeals. Most administrative appeals end up in the judicial section of the Council of State (Raad van State).

- $\quad$ Sweden has a system of administrative law courts, which is separate from the general court system and generally tries cases relating to disputes between private citizens and government authorities. The Swedish administrative law court system has three tiers, with 12 county administrative courts (förvaltningsrätt) as the first tier, four administrative courts of appeal (kammarrätt) as the second tier, and the Supreme 
Administrative Court of Sweden (Regeringsrätten) as the third tier (“Sveriges Domstolar”).

This provides an alternative model for consideration, under which separate courts could be established pursuant to Article III and operate under the District Courts in the Judicial Branch. The proposed alignment would be a District Administrative Law Court within each Judicial District, which would hear all disputes for which the subject matter is located within that Judicial District, with appeals form Administrative Law Courts to the Circuit Court of Appeals to which all other cases from that Judicial District are appealed.

Advantages of separating administrative courts from administrative agencies, based upon either the independent Office of Administrative Hearings concept or the Article III courts concept, would include the following:

- $\quad$ Disputes would be decided by ALJs or other judicial officers removed from the possibility of undue influence by agency executive directors, staffs, and governing bodies.

- $\quad$ Citizens facing conflicting guidance from different agencies would have a forum to consolidate proceedings and obtain an answer that would apply to all parties and agencies.

- $\quad$ Citizens would be able to access a forum having at least the appearance of impartiality without first having to incur the time and expense required to exhaust remedies within the administrative system.

- $\quad$ Citizens would be able to have administrative disputes adjudicated within reasonable proximity of their geographic location.

- Dedicated administrative law courts would be able to develop a high level of expertise in dealing with administrative law issues, addressing to a great extent the technical expertise argument in favor of administrative agencies.

Following existing administrative procedures, under the Office of Administrative Hearings approach or the Article III Administrative Law Court approach, the court would not have the final word. It would issue Findings of Fact, Conclusions of Law, and Proposed Disposition to the appropriate agency, which would have the final decision. Obviously, should the agency dispose of the matter in a way contrary to the recommendation of the court, the citizen or citizens would potentially have a very strong case on appeal.

\section{CONCLUSION}

The federal administrative law process violates the constitutional principle of separation of powers. This has been allowed to stand historically in order to promote efficiency and equity in carrying out the will of Congress as expressed in the enabling legislation for each agency. Proposals have been made to change this by requiring congressional ratification of agency rules and regulations. Other changes which merit consideration include imposing a sunset review of existing rules and regulations, and moving the administrative law courts out of the agencies themselves, into either a separate office in the Executive Branch or to the Judicial Branch, in order to avoid at least the appearance of potential bias in favor of the agency.

\section{AUTHORS}

Robert B. Matthews, Assistant Professor, Sam Houston State University, holds a J.D. from University of Houston, an M. Accounting and a B.A. from Rice University, and is licensed in Texas as an attorney and a certified public accountant. E-mail: RBM003@SHSU.EDU (Corresponding author)

Tommy J. Robertson, Assistant Professor, Sam Houston State University, holds a J.D. from South Texas College of Law and is licensed in Texas as an attorney.

Laura L. Sullivan, J.D., Associate Professor, Sam Houston State University, holds a J.D. from South Texas College of Law, an M.B.A. from Sam Houston State University, and a B.B.A. from the University of Houston, and is licensed in Texas as an attorney. 


\section{REFERENCES}

1. Anthony, Robert, 11 Aug 1998, "Unlegislative Compulsion: How Federal Agency Guidelines Threaten Your Liberty," Cato Institute Policy Analysis, No. 312.

2. Bovard, James, July 1999, "The Mirage of Administrative Justice," accessed 11 November 2011 at http://www.fff.org/freedom/0799d.asp

3. Darity, William A. (editor), 2008, International Encyclopedia of the Social Sciences, $2^{\text {nd }}$ Edition, Independence, KY, USA: Macmillan Reference USA.

4. DeLong, James, 2002, Out of Bounds, Out of Control: Regulatory Enforcement and the EPA, Washington, DC, USA: Cato Institute.

5. $\quad$ Freytag v. Commissioner of Internal Revenue, 1991, 501 U.S. 868.

6. $\quad$ Gilmore v. Lujan, 1991, 641 F2d 1409 (9th Ckt).

7. Harwood, Gerald, 1984, "How Necessary is the Administrative Law Judge," Western New England Law Review, Vol. 6, pp. 793-805, accessed 15 December 2012 at http://assets.wne.edu/160/39 arti_How_Nece.pdf

8. $\quad$ Immigration and Naturalization Service v. Chadha, 1983, 462 U.S. 919.

9. Joint Administrative Procedures Committee, 2010, A Pocket Guide to Florida's Administrative Procedure Act, Tallahassee, FL, USA: State of Florida.

10. Lawson, Gary, Summer 1999, "Delegation and the Constitution," Regulation, Washington, DC, USA.

11. Lawson, Gary, January 2005, "Discretion as Delegation: The 'Proper' Understanding of the Nondelegation Doctrine," George Washington Law Review, Vol. 73.

12. Lowi, Theodore, 1979, The End of Liberalism: The Second Republic of the United States, 2nd ed., New York, NY, USA: W. W. Norton.

13. Lowi, Theodore, 1987, "Two Roads to Serfdom: Liberalism, Conservatism, and Administrative Power," American University Law Review, Vol. 36.

14. $\quad$ Mistretta v. United States, 1989, 488 U.S. 361.

15. Morgan v. United States, 1938, 304 U.S. 1.

16. Schoenbrod, David, 1993, Power Without Responsibility: How Congress Abuses the People through Delegation, New Haven, CT, USA: Yale University Press.

17. Schoenbrod, David, Winter 2003, "Politics and the Principle that Elected Officials Should Make the Laws," Harvard Journal of Law and Public Policy, Vol. 26.

18. Sweden, Government of, "Sveriges Domstolar (The Swedish Courts)," accessed 7 Nov 2011 at http://www.domstol.se/templates/DV_InfoPage_2317.aspx

19. Texas Sunset Advisory Commission, 2012, "Sunset Advisory Commission," accessed 17 December 2012 at http://www.sunset.state.tx.us/

20. Universal Camera Corp. v. NLRB, 1951, 340 U.S. 474. 


\section{NOTES}

